\title{
Assessment of strawberry varieties by anthracnose resistance gene
}

\author{
Alexander Lyzhin*, and Irina Luk'yanchuk \\ Federal State Scientific Institution «I. V. Michurin Federal Scientific Center», 30 st. Michurina, \\ Michurinsk, 393774
}

\begin{abstract}
The results of marker-assisted identification of the Rca2 anthracnose resistance gene in promising strawberry varieties were shown. The DNA marker STS-Rca2_240, linked to the Rca2 anthracnose resistance allele was identified in varieties Albion and Aprica $(F . \times$ ananassa), and variety $\operatorname{Dar}(F . \times$ anashata $)$. Strawberry varieties Alpha, Bereginya, Kokinskaya Zarya, Pamyati Zubova, Rubinovy kaskad, Slavutich, Yuniol, Big King, Brilla, Joly, Rumba and Vivara are characterized by the absence of the marker STS-Rca2_240. In strawberry varieties with the identified marker STS-Rca2_240 (Dar, Albion and Aprica), the Rca2 gene can be in a dominant homozygous or heterozygous state, which makes it possible to recommend these genotypes for use in breeding for anthracnose resistance.
\end{abstract}

Strawberry is susceptible to many fungal, bacterial and viral diseases. The most important strawberry fungal diseases are powdery mildew, gray mold rot, white and brown leaf spots, anthracnose, red stele root rot and verticillium wilt [1-4].

Anthracnose is one of the most dangerous fungal diseases of strawberry. Anthracnose is caused by phytopathogenic fungi of the genus Colletotrichum: Colletotrichum acutatum J.H. Simmonds, C. gloeosporioides (Penz.) Penz. \& Sacc. And C. fragariae A.N. Brooks (some researchers combine $C$. fragariae and $C$. gloeosporioides into the $C$. gloeosporioides species complex) [5-7]. In the temperate climatic zone, the $C$. acutatum species complex is most common [8-10]. In Europe and the Eurasian Economic Union, C. acutatum is a quarantine pathogen $[11,12]$.

According to the studies of European researchers, the strawberry resistance to some isolates of $C$. acutatum is controlled by the dominant Rca2 gene. Identification of genetic determinants of this trait allows for targeted selection of promising strawberry forms using diagnostic molecular markers [13-15].

The purpose of the study was assess the allelic diversity of the Rca2 anthracnose resistance gene in strawberry varieties to identify promising genotypes for involvement in the strawberry breeding to create resistant to fungal pathogens forms.

The studies were carried out in 2020-2021. Biological material was represented by promising strawberry varieties from genetic collection of the FSSI "I.V. Michurin Federal Scientific Center" (Table 1).

\footnotetext{
*Corresponding author: Ranenburzhetc@yandex.ru
} 
Table 1. Analyzed strawberry varieties

\begin{tabular}{|c|c|c|}
\hline Variety & Crossing combination & Origin / Originator \\
\hline Dar & $\begin{array}{l}F . \times \text { ananassa Duch. } \times F . \\
\text { moschata Duch. }\end{array}$ & Russia \\
\hline Alpha & $\begin{array}{l}\text { Festivalnaya romashka } \times \\
\text { Syurpriz olimpiade }\end{array}$ & \multirow{4}{*}{$\begin{array}{l}\text { Federal Horticultural Research } \\
\text { Center for Breeding, } \\
\text { Agrotechnology and Nursery, } \\
\text { Russia }\end{array}$} \\
\hline Bereginya & Solovushka $\times$ Induka & \\
\hline Kokinskaya zarya & Slavutich $\times 157-7$ & \\
\hline Slavutich & $\begin{array}{l}\text { Festivalnaya romashka } \times \\
\text { Syurpriz olimpiade }\end{array}$ & \\
\hline Pamyati Zubova & $\begin{array}{l}{[\text { Feyerverk } \times(\text { Belrubi } \times} \\
F . \text { ovalis Rydb. })] \times \text { Holiday }\end{array}$ & \multirow{2}{*}{$\begin{array}{l}\text { I.V. Michurin Federal Scientific } \\
\text { Center, Russia }\end{array}$} \\
\hline $\begin{array}{l}\text { Rubinovyy } \\
\text { kaskad }\end{array}$ & $922-67 \times$ Privlekatelnaya & \\
\hline Yuniol & No information available & $\begin{array}{l}\text { The Labor Red Banner Order } \\
\text { Nikita Botanical Gardens - } \\
\text { National Scientific Center of } \\
\text { Russian Academy of Sciences, } \\
\text { Republic of Crimea, Russia }\end{array}$ \\
\hline Big King & No information available & Russia \\
\hline Albion & Diamante $\times$ Cal 94.16-1 & $\begin{array}{l}\text { University of California Davis, } \\
\text { USA }\end{array}$ \\
\hline Brilla & FC 04.256 .32 & $\begin{array}{l}\text { CRA-Unità di Ricerca per la } \\
\text { Frutticoltura, Italy }\end{array}$ \\
\hline Joly & $\mathrm{T} 2-6 \times \mathrm{A} 20-17$ & \multirow{4}{*}{$\begin{array}{l}\text { Consorzio Italiano Vivaisti } \\
\text { (CIV), Italy }\end{array}$} \\
\hline Aprica & No information available & \\
\hline Laetitia (control) & No information available & \\
\hline Vivara & No information available & \\
\hline Rumba & No information available & Fresh Forward B.V., Netherlands \\
\hline
\end{tabular}

The allelic state of the Rca2 anthracnose resistance gene was identified by DNA analysis using the diagnostic marker STS-Rca2_240. The marker STS-Rca2_240 is represented by a $240 \mathrm{bp}$ amplicon, which is amplified only if the $R c a 2$ anthracnose resistance allele is present in the strawberry genotype. The SSR marker EMFv020 was used as the positive PCR control. The target fragment of marker EMFv020 (amplicon size about $170 \mathrm{bp}$ ) is present in all strawberry genotypes [16]. The control of the presence of the Rca2 anthracnose resistance allele in the genome was the strawberry variety Laetitia. According to previous studies, the strawberry variety Laetitia is characterized by a dominant homozygous or heterozygous genotype (Rca2Rca2 or Rca2rca2) [17].

Polymerase chain reaction (PCR) was performed in T100 Thermal Cycler (BIO-RAD) according to the previously described program $[17,18]$.

Amplification products were separated by electrophoretic method in agarose gel (agarose concentration $-2 \%$, running buffer $-1 \mathrm{x}$ TBE). Amplicon sizes estimated were performed using the Gene Ruler 100 bp DNA Ladder (Thermo Fisher Scientific).

In the analyzed strawberry collection, the marker STS-Rca2_240 was identified in the varieties Albion and Aprica $(F . \times$ ananassa $)$, and variety Dar $(\bar{F} \times$ anashata $)$. Strawberry varieties Alpha, Bereginya, Kokinskaya Zarya, Pamyati Zubova, Rubinovy kaskad, Slavutich, Yuniol, Big King, Brilla, Joly, Rumba and Vivara are characterized by the absence of the target fragment of the STS-Rca2_240 marker. The example of 
electrophoretic profiles of marker fragments of the Rca2 gene in strawberry varieties is shown in Figure; the results are shown in Table 2.

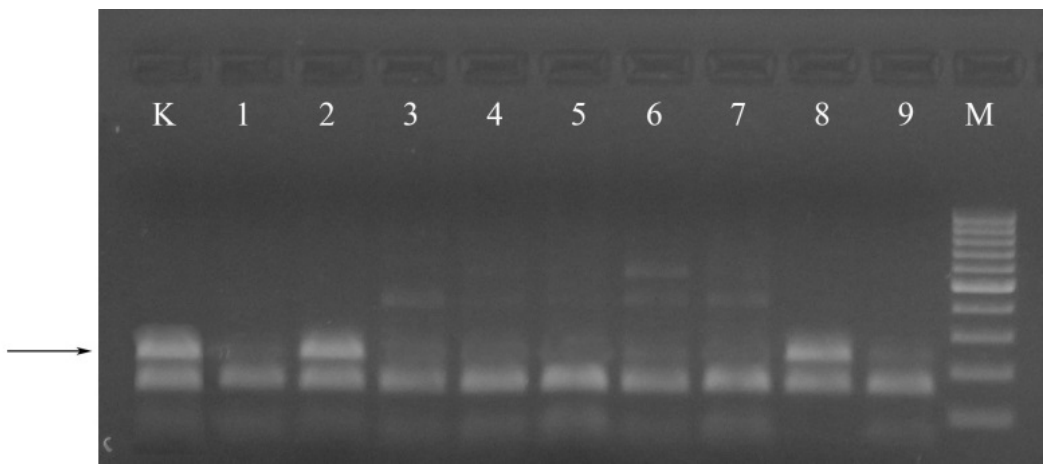

Fig. Electrophoresis profile of marker STS-Rca2 240 at strawberry varieties K - control (Laetitia), 1 - Rumba, 2 - Aprica, 3 - Pamyati Zubova, 4 - Rubinovyy kaskad, 5 - Brilla, 6 - Big king, 7 - Slavutich, 8 - Albion, 9 - Yuniol, M-Molecular weight marker

Table 2. Polymorphism of the Rca 2 anthracnose resistance gene in strawberry varieties $(1-$ allele is present, 0 - allele is absent)

\begin{tabular}{|c|c|c|c|}
\hline № & Variety & Marker STS-Rca2_240 & Genotype \\
\hline 1 & Alpha & 0 & rca2rca2 \\
\hline 2 & Bereginya & 0 & rca2rca2 \\
\hline 3 & Dar & 1 & Rca2Rca2 or Rca2rca2 \\
\hline 4 & Kokinskaya zarya & 0 & rca2rca2 \\
\hline 5 & Pamyati Zubova & 0 & rca2rca2 \\
\hline 6 & Rubinovyy kaskad & 0 & rca2rca2 \\
\hline 7 & Slavutich & 0 & rca2rca2 \\
\hline 8 & Yuniol & 0 & rca2rca2 \\
\hline 9 & Albion & 1 & Rca2Rca2 or Rca2rca2 \\
\hline 10 & Aprica & 1 & Rca2Rca2 or Rca2rca2 \\
\hline 11 & Big King & 0 & rca2rca2 \\
\hline 12 & Brilla & 0 & rca2rca2 \\
\hline 13 & Joly & 0 & rca2rca2 \\
\hline 14 & Laetitia (control) & 1 & Rca2Rca2 or Rca2rca2 \\
\hline 15 & Rumba & 0 & rca2rca2 \\
\hline 16 & Vivara & 0 & rca2rca2 \\
\hline
\end{tabular}

It should be noted that strawberry varieties Pamyati Zubova, Big King and Slavutich, in addition to fragments of a known size, have additional amplicons. Strawberry varieties Pamyati Zubova and Slavutich have an amplicon of about $400 \mathrm{bp}$. Strawberry variety Big king has an amplicons of about 400 and $500 \mathrm{bp}$. These amplicons are presumably unrelated to anthracnose resistance.

Strawberry varieties with the identified marker STS-Rca2_240 (Dar, Albion and Aprica) are characterized by the presence of the Rca 2 anthracnose resistance allele in a dominant homozygous or heterozygous state. To accurately determine the allelic state of the $R c a 2$ gene in these strawberry varieties, additional research is needed.

Thus, as a result of the molecular genetic analysis, the $R c a 2$ anthracnose resistance gene was identified in varieties Albion and Aprica $(F . \times$ ananassa), and variety $\operatorname{Dar}(F . \times$ 
anashata), which makes it possible to recommend these genotypes for use in breeding to create resistant to $C$. acutatum strawberry varieties.

\section{References}

1. J.L. Maas, Acta Hortic. 133-142 (2014) https://doi.org/10.17660/actahortic.2014.1049.11

2. S.M. Mirmajlessi, M. Destefanis, R.A. Gottsberger, M. Mänd, E. Loit, Syst. Rev., 4, 9 (2015) https://doi.org/10.1186/2046-4053-4-9

3. S. Petrasch, S.J. Knapp, J.A.L. van Kan, B. Blanco-Ulate, Molecular plant pathology 20(6), 877-892 (2019) https://doi.org/10.1111/mpp.12794

4. A.S. Lyzhin, I.V. Luk'yanchuk, Proceedings of the national academy of sciences of Belarus. Agrarian series 58(3), 311-320 (2020) https://doi.org/10.29235/1817-72042020-58-3-311-320

5. R.S. Jayawardena, J.K. Huang, B.C. Jin, J.Y. Yan, X.H. Li, K.D. Hyde, A.H. Bahkali, S.L. Yin, G.Z. Zhang, Mycosphere, 7(8), 1147-1191 (2016) https://doi.org/10.5943/mycosphere/si/2c/6

6. B.B. Forcelini, S. Lee, M.S. Oliveira, N.A. Peres, Phytopathol., 108(12), 1501-1508 (2018) https://doi.org/10.1094/PHYTO-04-18-0128-R

7. C.F. Nellist, In: T. Hytönen, J. Graham, R. Harrison (eds) The Genomes of Rosaceous Berries and Their Wild Relatives, 79-94 (Springer, Cham., 2018) https://doi.org/10.1007/978-3-319-76020-9 7

8. U. Damm, P.F. Cannon, J.H.C. Woudenberg, P.W. Crous, Stud. Mycol., 73, 37-113 (2012) https://doi.org/10.3114/sim0010

9. N.A. Holod, Yu.P. Kashchits, E.A. Dobrenkov, L.G. Semenova, Fruit growing and viticulture of South Russia 51(3), 137-145 (2018) https://doi.org/10.30679/2219-5335$\underline{\text { 2018-3-51-137-145 }}$

10. K. Karimi, M. Arzanlou, I. Pertot, Front. Microbiol., 10, 129 (2019) https://doi.org/10.3389/fmicb.2019.00129

11. E.J. Calleja, B. Ilbery, N.J. Spence, P.R. Mills, Plant Pathol., 62(2), 266-278 (2013) https://doi.org/10.1111/j.1365-3059.2012.02647.x

12. A.A. Kuznetsova, I.P. Dudchenko, M.B. Kopina, Modern approaches and methods in plant protection, 70-73 (2018) https://elar.urfu.ru/bitstream/10995/86511/1/978-5-79962278-7 2018 032.pdf

13. M. Sturzeanu, M. Coman, M. Ciuca, I. Ancu, D. Cristina, A.G. Turcu, Acta Hortic., 1139, 107-112 (2016) https://doi.org/10.17660/ActaHortic.2016.1139.19

14. N.V. Bassil, K.E. Hummer, C.E. Finn, Acta Hortic., 1156, 25-35 (2017) https://doi.org/10.17660/ActaHortic.2017.1156.4

15. L. van Eck, J.M. Bradeen, In: T. Hytönen, J. Graham, R. Harrison (eds), The Genomes of Rosaceous Berries and Their Wild Relatives, 63-75 (2018) https://doi.org/10.1007/978-3-319-76020-9 6

16. M.A. Miller-Butler, B.J. Smith, B.R. Kreiser, E.K. Blythe, HortScience, 54(5), 793-798 (2019) https://doi.org/10.21273/HORTSCI13805-18

17. I.V. Luk'yanchuk, A.S. Lyzhin, I.I. Kozlova, Vavilov Journal of Genetics and Breeding 22(7), 795-799 (2018) https://doi.org/10.18699/VJ18.423

18. A.S. Lyzhin, I.V. Lukyanchuk, E.V. Zhbanova, Proceedings on Applied Botany, Genetics and Breeding 180(1), 73-77 (2019) https://doi.org/10.30901/2227-8834-2019$\underline{1-73-77}$ 